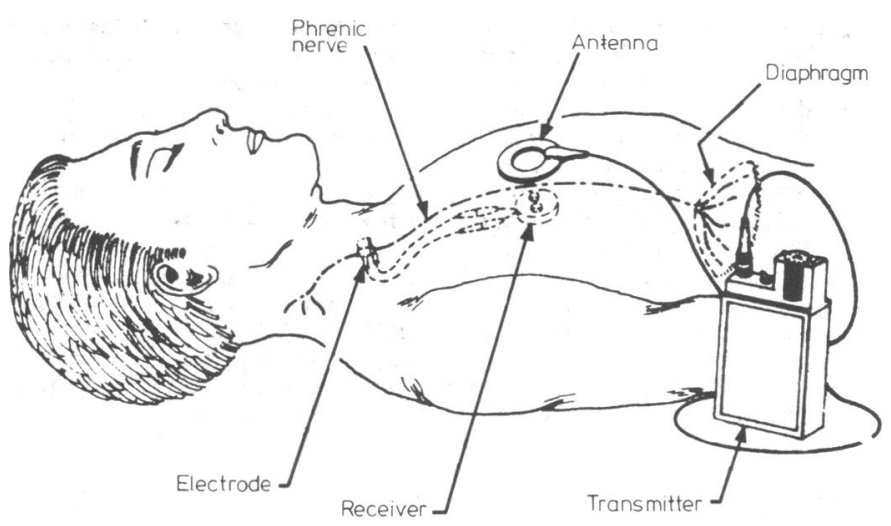

Diaphragm pacer.

respiratory muscles. ${ }^{45}$ Patients with central alveolar hypoventilation were selected on the basis of several criteria, including the presence of clinical features of chronic hypoventilation and reduced ventilatory response to hypoxia and hypercapnia but near-normal results of tests of ventilatory capacity. There was clinical evidence of improvement in right heart failure after pacing was started and a fall in packed cell volume and pulmonary artery pressure. The patient with chronic obstructive lung disease was paced with the aim of being able to give regular safe treatment with oxygen despite dependence on hypoxic drive. Pacing over 42 months brought about a decrease in the frequency of acute exacerbations and other evidence of improvement including a fall in the packed cell volume.

Quadriplegic patients with total respiratory paralysis require ventilatory support at all times. Continuous pacing of one or both hemidiaphragms using electrical variables standard for intermittent pacing produces fatigue, however, which, if prolonged, irreversibly damages the muscle. ${ }^{6}$ The hemidiaphragms are therefore paced alternately so that electrical stimulation of one side is never continued for longer than 16 hours. This gives each hemidiaphragm a rest period and avoids fatigue. Eight of the quadriplegic patients in Glenn's series were supported entirely jy diaphragm pacing for up to 10 years. Among the important benefits of pacing in quadriplegics with paralysis of the respiratory muscles are the social and psychological advantages of freedom from dependence on a mechanical ventilator.

The aim of this report is to increase awareness of the availability of diaphragm pacing for use in the management of patients with ventilatory insufficiency and intact lower-motorneurone innervation of the diaphragm.

We are grateful to Dr C J Goodwill for allowing us to publish this report and to the staff of the intensive care unit for their help. We also thank Miss Maggy Gleeson for secretarial help.

ADDENDUM-Since this paper was submitted we have implanted a similar bilateral diaphragm pacing system in a 2 -year-old boy with quadriplegia and consequent ventilatory failure. The system is functioning satisfactorily.

\section{References}

1 Judson JP, Glenn WWL. Radiofrequency electrophrenic respiration. FAMA 1968;203:1033-7.

2 Glenn WWL, Holcomb WG, Gee JBL, Rath R. Central hypoventilation; long-term ventilatory assistance by radiofrequency electrophrenic respiration. Ann Surg 1970;172:755-73.

${ }^{3}$ Glenn WWL, Holcomb WG, Hogan J, et al. Diaphragm pacing by radiofrequency transmission in the treatment of chronic ventilatory insufficiency. $\mathcal{F}$ Thorac Cardiovasc Surg 1973;66:505-20.

4 Glenn WWL. Diaphragm pacing-present status. PACE 1978;1:357-70.

${ }^{5}$ Glenn WWL, Hogan JF, Phelps ML. Ventilatory support of the quadriplegic patient with respiratory paralysis by diaphragm pacing. Surg Clin North Am 1980;60:1055-78.

${ }^{6}$ Liu HM, Loew JM, Hunt CE. Congenital hypoventilation syndrome: a pathologic study of the neuromuscular system. Neurology $1978 ; 28$ : 1013-9.

${ }^{7}$ Oda T, Glenn WWL, Hogan JF, et al. Evaluation of electrical parameters for diaphragm pacing: an experimental study. F Surg Res $1981 ; 30$ : 142-53.

(Accepted 18 August 1981)

\title{
Severe metabolic alkalosis: a case report
}

\section{SHAHROKH JAVAHERI, EDWARD A NARDELL}

\begin{abstract}
A 45-year-old man who was admitted with nausea, vomiting, and abdominal pain was found to have severe metabolic alkalosis, with a $\mathrm{PaCO}_{2}$ of $11.4 \mathrm{kPa}(85.5 \mathrm{~mm} \mathrm{Hg})$, $\mathrm{PaO}_{2}$ of $5.8 \mathrm{kPa}(43.5 \mathrm{~mm} \mathrm{Hg})$, $\mathrm{pH}$ of 7.61 , and plasma bicarbonate concentration of $82.0 \mathrm{mmol} / 1$. He was treated with oxygen, intravenous physiological saline, and phenytoin and improved within 48 hours. Radiographs showed gastric outlet obstruction secondary to peptic ulcer, which was treated by surgery.

Though severe, the rise in carbon dioxide concentration in this patient was probably lifesaving. The $\mathbf{P a c o}_{2}$ was
\end{abstract}

Pulmonary Division, Boston University Medical Center and Boston City Hospital, Boston, Mass 02118, USA

SHAHROKH JAVAHERI, MD, assistant professor of medicine (present address: Laboratory of Normal and Pathological Physiology, University of Gent, B-9000 Gent, Belgium)

EDWARD A NARDELL, MD, assistant professor of medicine (present address: Harvard Medical School, Department of Medicine, Cambridge Hospital, Cambridge, MA 02139, USA) therefore allowed to fall gradually as the alkalosis was treated. The return of both $\mathrm{PaCO}_{2}$ and plasma bicarbonate values to normal in parallel suggests that hypoventilation compensated for the metabolic alkalosis and emphasises the importance of conservative treatment in cases of metabolic alkalosis.

\section{Introduction}

We report a patient with severe metabolic alkalosis, out of the range of most acid-base nomograms. The metabolic alkalosis was due to vomiting secondary to gastric outlet obstruction. The initial arterial plasma bicarbonate concentration was $82 \mathrm{mmol}(\mathrm{mEq}) / \mathrm{l}$, but it returned to normal within 48 hours of the start of treatment.

\section{Case report}

A 45-year-old man was admitted with a two-day history of nausea, vomiting, and abdominal pain. He had a history of alcohol withdrawal seizures. He had symptoms of peptic ulcer and an upper gastro- 
intestinal $x$-ray examination six years earlier had shown a scarred duodenal bulb and acute duodenal ulcer. He was taking hydrochlorothiazide for hypertension. There was no history of chronic obstructive pulmonary disease.

On admission the patient was stuporous and had dry skin. His reflexes were normal. The blood pressure was $130 / 70 \mathrm{~mm} \mathrm{Hg}$, pulse rate $92 / \mathrm{min}$, respiratory rate $12 / \mathrm{min}$, and rectal temperature $38.3^{\circ} \mathrm{C}$. Packed cell volume was $49 \cdot 8^{\circ}$, and white blood cell count $15.3 \times 10^{9} / 1$. Blood urea nitrogen was $10 \mathrm{mmol} / 1(28 \mathrm{mg} / 100 \mathrm{ml})$. Serum amylase activity was normal. Serum sodium was $142 \mathrm{mmol}(\mathrm{mEq}) / \mathrm{l}$, potassium $2.0 \mathrm{mmol}(\mathrm{mEq}) / 1$, and chloride $50 \mathrm{mmol}(\mathrm{mEq}) / 1$. Arterial carbon dioxide tension $\left(\mathrm{PaCO}_{2}\right)$ was $11.4 \mathrm{kPa}(85.5 \mathrm{~mm} \mathrm{Hg})\left(\right.$ at $\left.37^{\circ} \mathrm{C}\right)$ and oxygen tension $\left(\mathrm{PaO}_{2}\right) 5.8 \mathrm{kPa}(43.5 \mathrm{~mm} \mathrm{Hg}), \mathrm{pH} 7.61$, and the calculated plasma bicarbonate $82.0 \mathrm{mmol}(\mathrm{mEq}) / \mathrm{l}$. Initially he was treated with naloxone without response. Oxygen, intravenous physiological saline, potassium chloride, and phenytoin were administered. He improved within the next 48 hours (see table) but developed aspiration pneumonitis while in the intensive care unit.

Acid-base variables during patient's stay in hospital (values corrected to patient's body temperature

\begin{tabular}{|c|c|c|c|c|c|}
\hline Time: & Admission & $\begin{array}{c}6 \text { hours } \\
\text { later }\end{array}$ & $\begin{array}{l}12 \text { hours } \\
\text { later }\end{array}$ & $\begin{array}{l}24 \text { hours } \\
\text { later }\end{array}$ & $\begin{array}{l}48 \text { hours } \\
\text { later }\end{array}$ \\
\hline $\begin{array}{l}\mathrm{F}_{1} \mathrm{O}_{2} \\
\mathrm{PaO}_{2}(\mathrm{kPa}) \\
\mathrm{PaCO}_{2}(\mathrm{kPa}) \\
\mathrm{pH}^{\mathrm{HCO}} \quad .\end{array}$ & $\begin{array}{l}0 \cdot 21 \\
5 \cdot 8 \\
11 \cdot 4 \\
7 \cdot 59 \\
82\end{array}$ & $\begin{array}{c}0 \cdot 40 \\
14 \\
9 \cdot 7 \\
7 \cdot 56 \\
65\end{array}$ & $\begin{array}{c}0 \cdot 35 \\
10 \cdot 9 \\
10 \cdot 3 \\
7 \cdot 47 \\
55\end{array}$ & $\begin{array}{c}0.35 \\
12 \cdot 7 \\
7 \cdot 5 \\
7 \cdot 43 \\
35 \cdot 5\end{array}$ & $\begin{array}{c}0 \cdot 21 \\
10 \cdot 5 \\
4 \cdot 7 \\
7 \cdot 43 \\
23 \cdot 8\end{array}$ \\
\hline
\end{tabular}

$\mathrm{F}_{1} \mathrm{O}_{2}=$ Fractional concentration of inspired oxygen.

Conversion: SI to traditional units $-\mathrm{PaO}_{2}$ and $\mathrm{PaCO}_{2}: 1 \mathrm{kPa} \approx 7.5 \mathrm{~mm} \mathrm{Hg}$.

Two days after admission his serum sodium was $146 \mathrm{mmol} / 1$, potassium $3.8 \mathrm{mmol} / \mathrm{l}$, and chloride $102 \mathrm{mmol} / \mathrm{l}$. Blood urea nitrogen was $5.7 \mathrm{mmol} / 1(16 \mathrm{mg} / 100 \mathrm{ml})$ and serum creatinine $80 \mu \mathrm{mol} / 1(0.9 \mathrm{mg} /$ $100 \mathrm{ml}$ ). Radiographs of the upper gastrointestinal tract showed gastric outlet obstruction secondary to peptic ulcer, for which he underwent surgery.

His pulmonary function tests showed a forced vital capacity (FVC) of $4.011(80 \%$ of predicted), forced expiratory volume in one second $\left(\mathrm{FEV}_{1}\right)$ of $3.39 \mathrm{l}(90 \%$ of predicted $), \mathrm{FEV}_{1}$ as a percentage of $\mathrm{VC}$ of $84 \%$, and maximum mid-expiratory flow rate of $3.981 /$ second $\left(108^{\circ}\right.$ of predicted).

Arterial blood gas analysis-Arterial blood gases were analysed by appropriate electrodes at $37^{\circ} \mathrm{C}$ (model 813, Instrumentation Laboratory, Lexington, Mass.) $\mathrm{PCO}_{2}$ and $\mathrm{Po}_{2}$ electrodes were calibrated by gases of known concentration as well as human blood tonometered with the same gases. The $\mathrm{pH}$ electrode was calibrated with precision buffers. The patient's arterial blood gas values were corrected to his body temperature and plasma bicarbonate was calculated from the Henderson-Hasselbalch equation by using a Severinghaus blood gas calculator.

\section{Discussion}

This patient suffered from the most severe metabolic alkalosis ever reported as a result of vomiting secondary to gastric outlet obstruction. Hydrochlorothiazide worsened the process. Hypoventilation, which prevented a lethal alkaline $\mathrm{pH}$, was at least partly due to the depression of central and peripheral chemoreceptors by the alkalaemia. The patient was not taking any drugs which would depress respiration, and he showed no response to naloxone.

Although grand mal seizure may lead to carbon dioxide retention and might have further augmented the rise in $\mathrm{PaCO}_{2}$, its contribution to hypoventilation in this patient was uncertain. A severe grand mal seizure is often associated with lactic acidosis resulting in an increased anion gap $\left(\left(\mathrm{Na}^{+}+\mathrm{K}^{+}\right)-\right.$ $\left(\mathrm{Cl}^{-}+\mathrm{HCO}_{\overline{3}}^{-}\right)$. This patient had a low anion gap initially. Nevertheless, if our patient had seizure-induced carbon dioxide retention, the contribution of such a sharp increase in carbon dioxide concentration to the rise in plasma bicarbonate concentration was minimal. Furthermore, chronic obstructive lung disease and carbon dioxide retention on that basis were ruled out by his history and by normal pulmonary function values and $\mathrm{PaCO}_{2} 48$ hours after treatment. The initial alveolar-arterial difference for oxygen tension, (A-a) $\mathrm{Do}_{2}$, was also normal.

It has been suggested that compensatory carbon dioxide retention in metabolic alkalosis is limited since the impending hypoxaemia and concomitant hypokalaemia ${ }^{1}$ prevent hypoventilation. Many patients with severe metabolic alkalosis and pronounced compensatory carbon dioxide retention have been hypoxaemic, ${ }^{2}$ however, and it is now well-known that the carotid body is less sensitive to hypoxaemia in the presence of alkalaemia. ${ }^{3}$ This patient initially had a $\mathrm{PaO}_{2}$ of $5.8 \mathrm{kPa}(43.5$ $\mathrm{mm} \mathrm{Hg}$ ).

We have shown ${ }^{4}$ that percentage regulation of hydrogen in the arterial blood of normal subjects with steady state metabolic alkalosis is independent of changes in plasma potassium concentrations. Other reported cases, moreover, have shown severe carbon dioxide retention compensatory to metabolic alkalosis with potassium depletion and hypokalaemia. ${ }^{2}$ This patient's initial plasma potassium concentration was $2.0 \mathrm{mmol} / 1$. Therefore, it does not follow that hypokalaemia would necessarily limit hypoventilation. On the contrary, respiratory muscle weakness secondary to hypokalaemia might itself have aggravated hypoventilation, although this probably did not contribute to carbon dioxide retention in our patient since his reflexes were intact.

Several recent studies have attempted to define more fully the normal ventilatory response to metabolic alkalosis. For a bicarbonate of $82 \mathrm{mmol} / \mathrm{l}$ our regression equation predicts a $\mathrm{PaCO}_{2}$ of $10.4 \mathrm{kPa}(75 \mathrm{~mm} \mathrm{Hg})$, while that of van Ypersele de Strihou ${ }^{5}$ predicts a $\mathrm{PaCO}_{2}$ of $12 \mathrm{kPa}(90 \mathrm{~mm} \mathrm{Hg})$. This patient's $\mathrm{PaCO}_{2}$ of $11.4 \mathrm{kPa}(85.5 \mathrm{~mm} \mathrm{Hg})$ was therefore, predicted reasonably accurately given the need to extrapolate beyond the data used to generate either regression equation.

Although very severe, the rise in carbon dioxide concentration in our patient was potentially lifesaving. It was therefore important to allow the $\mathrm{PCO}_{2}$ to fall gradually in response to treating the metabolic alkalosis. This gradual return of $\mathrm{PaCO}_{2}$ to normal concomitant with the return of plasma bicarbonate values to normal also suggests that hypoventilation was compensating for metabolic alkalosis in this patient. Moreover, the rapid recovery of our patient underscores the importance of conservative treatment (volume expansion, potassium, and oxygen) even in the most severe cases of metabolic alkalosis; the normal kidney has a large capacity for excreting bicarbonate.

\section{References}

${ }^{1}$ Goldring RM, Cannon PJ, Heinemann HO, Fishman AP. Respiratory adjustment to chronic metabolic alkalosis in man. $\mathcal{F}$ Clin Invest 1968 47:188-202.

${ }^{2}$ Lifschitz MD, Brasch R, Cuomo AJ, Menn SJ. Marked hypercapnia secondary to severe metabolic alkalosis. Ann Int Med 1972;77:405-9.

${ }^{3}$ Hornbein TF, Roos A. Specificity of $\mathrm{H}$ ion concentration as a carotid chemoreceptor stimulus. F Appl Physiol 1963;18:580-4.

4 Javaheri S, Shore NS, Rose BD, Callahan BJ, Kazemi H. Respiratory compensation in metabolic acidosis and alkalosis in normal man. Am Rev Resp Dis 1980;121:356.

${ }^{5}$ van Ypersele de Strihou C, Frans A. The respiratory response to chronic metabolic alkalosis and acidosis in disease. Clin Sci Mol Med 1973;45: 439-48.

(Accepted 14 August 1981)

MANY attempt to cure a cold, by getting drunk. But this, to fay no worfe of it, is a very hazardous experiment. No doubt it may fometimes fucceed, by fuddenly reftoring the perfpiration; but when there is any degree of inflammation, which is frequently the cafe, frong liquors, inftead of removing the malady, will increafe it. By this means a common cold may be converted into an inflammatory fever.

(Buchan's Domestic Medicine, r786.) 